\title{
COULD GOD HAVE COMMANDED THE SLAUGHTER OF THE CANAANITES?
}

\author{
Stephen N. Williams
}

\begin{abstract}
Summary
This article is a slightly revised version of the Tyndale Lecture in Christian Ethics, delivered in 2010. It deals not with the narrowly historical question of the slaughter of the Canaanites, but with the theological question of the possibility of God's having commanded it. Its argument is that we should not conceive it as a possible divine command, unless we regard it as sorrowfully commanded, a commandment accommodated to conditions of human violence for which humans are responsible.
\end{abstract}

Only the curse of academic habit prevents our being chilled by the title of this lecture and, if this sounds like rhetorical fancy, it is only because many of us live in regions where we and our friends, families and compatriots never feel the sharp edge of the sword. The sharp edge of the subject, however, seems to be turned by the title of the lecture, for it is not: 'Did God command the slaughter of the Canaanites?' The question: 'Did God command...?' is a form of question about history, a 'form' of question because, while it is a question about an event in time, it is not one which historical investigation can answer. That is the question which is avoided in the title. Whether or not the book of Joshua gives us a reliable account of second-millennial events is disputed. Archaeological evidence is commonly invoked to show that the Late Bronze Age could not have witnessed conditions such as those described in it, which apparently purports to describe Late Bronze Age doings. Historical reconstructions are proposed to correct its picture of conquest or of occupation; the possibility has long been mooted of a 
more phased and gradual infiltration of the land than the narrative describes against its Pentateuchal background; internal revolt in Canaan is postulated to account for some of the turbulence whose echo reverberates through the book of Joshua, which posits invasion from without. $^{1}$

There is also the more fundamental question of genre. 'History' is not a simple, undifferentiated category in itself and certainly not if we apply it to the Hebrew Scriptures or OT. ${ }^{2}$ Scholarly attention has been paid to 'metaphorical' readings of narrative accounts in the book of Joshua. But it is not a theme which I visit here more than I engage with the wider subject of genre. This is not because I doubt or contest the exegetically and theologically fundamental nature of questions surrounding genre. It is because the problem of the slaughter of the Canaanites has arisen over the course of history on the basis of how the story is told in the text of Scripture. The story, as told in Joshua, reports a God-given command to slaughter the Canaanites. Christianity, like Judaism, includes the book in its Scriptures and that is where the problem lies, whether or not a surface reading is lacking in subtle grasp of metaphor or any other literary trope. Obviously, it is incumbent upon us to correct any massively unfortunate or disastrous readings of Joshua in church history if they do injustice to the text. But the question: 'Could God have commanded the slaughter of the Canaanites?' is designed to avoid embroilment in questions of historical background and genre in the interests of an enquiry in theological ethics. Such a design does not entail either tacitly acquiescing in scepticism about the historical value of Joshua or tacitly hesitating to endorse the position that the text does enshrine a core, literal claim. It is pursued in order to avoid trespassing on the turf of OT scholarship. So the question under consideration is whether it is

\footnotetext{
${ }^{1}$ All this is most familiar to OT scholars. Although we do not major on such questions, see J. Gordon McConville \& Stephen N. Williams, Joshua (Grand Rapids: Eerdmans, 2010) for the exegesis and theological interpretation which undergird this article, which adapts and develops the argument on 'The Question of Genocide' included in that volume (pp. 108-125). More detailed bibliographical references are found in that volume for some of the general points made in the present article in relation to biblical materials. As nothing in my argument hangs on a disputed translation of a biblical text, I am consistently quoting from the NIV.

2 I tend to distinguish between the 'Hebrew Scriptures' and the 'Old Testament' according to the order of the canonical books that they contain, which means that they are designations which can often be used interchangeably.
} 
conceivable - that is, theologically conceivable — that God commanded the slaughter of the Canaanites.

To put the question in this way is to introduce a difficulty which is bound to confront whomever asks it in the context of a single lecture, namely, that of avoiding general debate on the nature of God and of Scripture in the course of treating the specific issue before us. We are all familiar with disagreements that begin with reference to a particular point, perhaps a particular biblical text, and end with the acknowledgement that different views of God and of Scripture fundamentally underlie the disagreement. This is not a sign of failure in detailed controversy; on the contrary, it may clarify what is basically at issue. Yet, we need to try to steer a course that prevents our enquiry from being indistinguishable from a treatment entitled: 'The doctrines of God and of Scripture'. Our enquiry is certainly implicitly about these, but directed to a more specific question.

It is a truism, and so needs no elaboration, that the texts in Joshua which record God's command to slay need careful handling in the contemporary world. It may well turn out that, theologically, both the dismay expressed towards and the defence offered on behalf of Joshua's actions, over the last two millennia, are familiar and sufficient, leaving us with little more to do than to recycle the issues involved. But in our post-Christian times, if that is how we should label them (with the Western world especially in mind) arguments which are formally and materially identical with those of the past might acquire a distinctive cultural force in the present. Perhaps it is worth specifying four things in this connection.

The first is that genocide is a publicised and painful theme in today's world. Whether or not the account contained in Joshua conforms to legal definition in that respect, we are encountering a cognate phenomenon in this book. The second is the continued conflict in the Middle or Near East, featuring Israel and the Arab world. Of course, this involves issues of rights to land which can be discussed independently of the particular problem that meets us in Joshua, but Joshua is at the heart of those Scriptures that have forged and enshrine the sense of Jewish identity. The third uneasily joins these two points: it is alleged that Israel actually introduced 'herem [sic] ideology and practice into world history', 'hêrem' being the devotion of people as well as of objects to destruction before the Lord, as in the book of 
Joshua. $^{3}$ I do not know how well founded this claim is, but its possibilities provide food for thought. The fourth is that much of the New Atheist attack on Christianity, which has made inroads into our schools in the United Kingdom, and is becoming a substratum in popular consciousness, pounces on its deleterious social consequences. Of course, it is not New Atheists alone, but many who join in the wider rejection of Christianity, who seize on this facet of religion. If Christianity were simply an intellectual folly, that would be damaging enough; as a social force, it is extremely destructive. The perceived connection between religion and violence is at the heart of this discussion. Joshua does not seem to help the Christian case. While the following discussion is not ordered to these four points, they give it a contemporary contextual significance. ${ }^{4}$

Reference to Christianity recalls us to what has seemed blatantly evident to a number of people over the centuries, namely, that there is a gulf between the way in which Yahweh is represented in the OT and the way in which God is revealed in Jesus Christ in the NT. Surely the God of Jesus Christ could not have commanded the slaughter of the Canaanites. In some circles, recording this demurral may appear more to throw us back to the early days of theological liberal-conservative debate than to attend to the status quaestionis today. But it depends on whether we simply look at the academy. As a matter of fact, even if we confine ourselves to the academy, we discover often enough that unsophisticated questions and tenets lie at the bottom of apparently more refined questions and convictions, a discovery which comes as a welcome relief to those of us who need reassurance that academics still belong to the human race, notwithstanding the heady pace and discriminating vagaries of social evolution. Nor do we really need to look below the surface. Discussion is doubtless more nuanced, refined and informed as a result of progress in biblical studies; nonetheless, the question posed by Marcion about the relationship of Testaments Old and New remains. The conviction that there is a contrast between the

\footnotetext{
${ }^{3}$ So Cowles, in C. S. Cowles et al, Show Them No Mercy: Four Views on God and Canaanite Genocide (Grand Rapids: Eerdmans, 1978): 100, characterises Eugene Merrill's position. If this is judged an accurate characterisation, the word 'ideology' must be very heavily underlined in this sentence.

${ }^{4}$ For more direct engagement with New Atheism, see Stephen N. Williams, 'Holy War and the New Atheism' forthcoming in Holy War in the Bible: Christian Morality and an Old Testament Problem, ed. Heath Thomas, Jeremy Evans and Paul Copan (Downers Grove, Illinois: IVP, 2013).
} 
God of the Old and of the New Testaments remains alive and well. Its sources vary, but it is to be treated with every theological and moral respect, particularly when it stems from pained perplexity or studious protection of divine goodness, rather than from impatient and snap dogmatism. Acute sensitivity to human suffering and meditation on the life of Christ readily combine to make the God of Joshua appear in salient respects as a disturbing stranger at best. ${ }^{5}$

To deal directly with the claim that there is a discrepancy between the God of the Old and God of the New Testament would be to enter into that more general investigation to which we alluded earlier and which threatens to upstage all other discussion. In avoiding direct engagement, no cavalier dismissal of this outlook is intended. Profound questions on the nature of the Christian Scriptures obviously arise at this point. In Joshua, which is the bridge by which we cross over from the Pentateuch into the Former Prophets (or the Historical Books) we are certainly not at the margins of the OT. If God never gave land to Israel, the story of the OT collapses as entirely as did the walls of Jericho; and if he did give the land, but never designed the slaughter, quite apart from the question of what mechanism God did intend for the acquisition of the land, we are confronted by a very radical mistake indeed in the OT apprehension of God and his word. This is admittedly a very flat-footed way of stating the issue and, obviously, many will unhesitatingly judge that what is here described in terms of undermining the OT (but which, suitably tweaked, could be termed its deconstruction) is something that we ought to do and not to avoid. It is a fair price to pay in moral-theological transaction; the alternative is to pay far too high a price in survey costs alone, if we seriously propose to explore positively an affirmation that God could have commanded the slaughter of the Canaanites. It is in full awareness of this judgement that I nevertheless proceed with the enquiry. ${ }^{6}$

\footnotetext{
${ }^{5}$ In this connection, it is salutary to read Origen's Homilies on Joshua (Washington: Catholic University of America, 2002; tr. by Barbara J. Bruce). Origen’s regular figural verbal substitution of 'Jesus' for 'Joshua' creates a suggestive dissonance.

6 Perhaps, in this article, I shall pay the price for not properly heeding Oliver O'Donovan's warning to attend, on its own terms, to a heroic warrior society and his encouragement to us to practise 'a suspension of moral judgement to allow an ancient society constructed on different terms from any we know to express its own moral priorities', quoted in Craig Bartholomew's introduction to Bartholomew et al., A Royal Priesthood: A Dialogue with Oliver O'Donovan (Carlisle: Paternoster, 2002): 36. And perhaps a further price is paid for failing to give time to those hermeneutical strategies of reading the account of the Canaanites that may save some of my readers from
} 
Three preliminary remarks are in order about the picture which appears before us in the book of Joshua. Firstly, readers have long pondered the relation between what happens in Joshua and what is prescribed through Moses in the book of Deuteronomy. What happens to Canaanite people and property in Joshua is (1) not the same in every case and (2) not always the same as what Deuteronomy enjoins, although nothing is more highlighted in the book of Joshua than the fidelity of Joshua's execution to Moses' legislation. We note here only that, where we are dealing either in Deuteronomy or in Joshua with the slaughter of the Canaanites, whatever differences we seem to discern, the scene is never described as typical of God's purpose for the people of Israel. However we respond to Israel's military enterprises in the OT, before or after Joshua, they are not systematically patterned on the peculiar set of injunctions that apply in the case of the Canaanites on the occasion of Israel's entry into Canaan. ${ }^{7}$

Secondly, we must guard against being misled by the wrong picture of life in the land. The moment that we reflect on what it was like before Israel arrived, we are reminded of Hobbes' celebrated description of the state of nature: 'nasty, brutish and short', if we may apply his adjectives in a different context. It is not just that its fortified towns testify to the fact that war was the order of the day. Child sacrifice seems also to have been the order of the day, a practice utterly detestable to God, as was the god Molech/Moloch, in whose name (if not only in its name) it was offered. Whatever the comparative moral condition of other peoples, we are told that God chose to give the Israelites Canaan in particular not on account of its geography and resources alone but also because of the corrupt nature of human conduct on the Canaanite scene, which God purposes to bring into judgement. The very land, as Leviticus puts it, is set to vomit out its inhabitants (18:28). Idolatry and social injustice, partners whose compact is firmer than the most secure human marriage, are rife. We might dare to suppose that life was so nasty and brutish for the vulnerable that it would come as a relief that it was short. It is no part of my proposal that this point be formally integrated into an argument in defence of slaughter, but let us at least get the picture right, even if the biblically-informed are unlikely to imagine Canaan as a land where

'wincing': see David Fergusson, Faith and Its Critics: A Conversation (Oxford: Oxford University Press, 2009): 162-63.

${ }^{7}$ Contrast Deut. 20:1-20. 
milk and honey was the paradisical lot of men, women and children before God's Israelites ruined it with a bout of holy hacking. ${ }^{8}$

Thirdly, we must also guard against being misled by the wrong picture at the other end, namely, the picture of the Israelite. It is not as though God transformed congenitally peace-loving nomads and shepherds into a fighting machine. We catch a glimpse of what the sons of Jacob could do in the book of Genesis when Simeon and Levi set out to avenge the rape of their sister, Dinah (Gen. 34:25-29). They are indeed the heirs, if not direct descendants, of Cain and Lamech (Gen. 4:24). The book of Joshua records divinely-directed violence in a world marked and marred by a violence that is human, all too human. Even if we espouse a theology which emphasises the divine appointment of all events, the distinction between divine and human violence is germane. It is a point which will turn out to be significant in the discussion that follows.

Reference to divine action exposes us to the standpoint which immediately confronts anyone who considers whether a positive answer can be given to the question: could God have commanded the slaughter of the Canaanites? The main theological reason for denying that he could have done so is that such a command is inconsistent with God's justice and goodness, the latter, in particular, embracing the love of God. In response, those who believe that it could have beenindeed, was-commanded tend to argue that the objection operates with an a priori view of God. It is a priori even if it is putatively grounded in Christology, for it presumes that we may readily infer from Christology conclusions about what God could and could not do, so providing pre-emptive valuation of the wider range of biblical materials. The position, it will be argued, in which we find ourselves, is this: the very Scripture which tells us that God issued the command in question also compels us to ascribe to God immutable justice and goodness. Therefore, we must believe both that the command was indeed possible and that it was compatible with justice and goodness. How this is so is a fitting subject of theological exploration, but it is an

\footnotetext{
${ }^{8}$ It must be remembered that we are adhering to the biblical picture in order to understand how to think theologically on its basis about the question before us. This picture of what the Canaanites were really like, as compared to Israelites, is often challenged. E.g. James Barr moves into this whole question, in connection with the problem of genocide, in the last chapter of his Gifford lectures on Biblical Faith and Natural Theology (Oxford: Clarendon, 1993).
} 
exploration that we should approach mindful that God's ways are not our ways and that his justice and goodness are not subject to our wellintentioned but inadequate canons or norms. Our conviction that all this is so must not be suspended upon the results of a theological enquiry as to how it can be so. So, broadly speaking, runs the defence of divine commandment at this point. It is a defence that leads us back to the fundamental issues of God and Scripture.

Attending to what Calvin says in his commentary on Joshua is a helpful way into a consideration of this defence, both because it enables us to keep our eye on Joshua while acknowledging the fundamental question in respect of God and Scripture and because of the massive influence of Calvin's thought on the clutch of issues in question. This was actually the last commentary that he wrote and it is interesting that an essayist who felt no need to subscribe to Calvin's theological position described it as 'the most direct and honest commentary on Joshua'. ${ }^{9}$ Calvin was never one to refuse to take the bull by the horns. He is straightforward. Commenting on the slaughter at Jericho, he says: 'As he, in whose hands are life and death, had justly doomed those nations to destruction, this puts an end to all discussion.' 10 Why was a whole people punished for the sin of Achan (Israelites, not Canaanites, in this case) ${ }^{11}$ Our minds are to be kept 'in suspense until the books are opened, when the divine judgements which are now obscured by our darkness will be most perfectly clear'. But children were executed along with Achan! Yes, but 'what here remains for us, but to acknowledge our weakness and submit to his [God's] incomprehensible counsel' (7:24)?. All this applies directly to the Canaanites. Calvin regards Joshua's destruction of the southern cities as barbaric: it was a 'detestable cruelty ... surpassing anything of which we read as having been perpetrated by savage tribes scarcely raised above the level of the brutes' (10:40). Yet, qua commanded by

\footnotetext{
${ }^{9}$ Ronald Goetz, 'Joshua, Calvin and Genocide', Theology Today 32 (1975): 263-74; quoted from 263.

${ }^{10}$ Calvin, Commentaries on the Book of Joshua (Grand Rapids: Eerdmans, 1949 repr.) on Joshua 6:20. From now on, I shall refer in the body of the text to the passage in Joshua on which Calvin is commenting.

${ }^{11}$ Achan, whose story is told in Joshua 7:1-26, is the Canaanite in Israel, as it were; the Hebrew consonants are directly reproduced in the 'cn' which we hear in 'Achan' and 'Canaan', although some English translations emend the alternative Hebrew rendering properly rendered 'Achar' in 1 Chronicles 2:7. We may add that Rahab, on the other hand, is the Israelite in Canaan (Josh. 2:1-14).
} 
God, it was morally right, for 'the judgement-seat of heaven is not subject to our laws'.

Two features in Calvin's treatment merit our attention. The first might easily slip by us. The OT story recounts the fact that three tribes-Reuben, Gad and the half-tribe, Manasseh-occupied their lands prior to the crossing of the Jordan into Canaan, but they were still obligated to help the other tribes to seize the land west of the Jordan. Accordingly, a number of their men crossed over but, Calvin notes, only a fraction of those numbered in the recent tribal census do so. Why only a fraction? Well, think of it. Moses, who had allocated their land to those tribes, would hardly want every man to leave wife and children behind. 'It would have been harsh and cruel to leave an unwarlike multitude unprotected in the midst of many hostile nations' (4:12-13). Morally, harshness and cruelty are utterly reprehensible. That is what Calvin assumes and believes. The second feature is that, at the same time as he appeals to God's inscrutable justice in commanding slaughter, Calvin does not leave matters there. He reminds us of the defilement which brought on this severe punishment, a defilement with which God had borne for four hundred years. This is a factor which weighs in the scale of justice. ${ }^{12}$ He reminds us as well that infants are, according to their nature, reprobate offspring of Adam's accursed race, who deserve to die. That being the case, Calvin observes that God might wish to spare some infants from the effects of the Adamic curse, in which case 'it may be that death proved to them a medicine’ (7:24), presumably to eschatological advantage. This, too, must be weighed in the scale.

It is precisely the reference to infants, which we might extend to all the powerless victims of evil regimes (women may especially come to mind), that touches on the heart of the difficulty, as it is commonly experienced. To the extent that the slaughter of warlike adult males is a judicial act carried out through the executive ministry of Israel, many will have no particular difficulty. Others, of course, will, and still

\footnotetext{
12 Hans Boersma, e.g., protests that 'the Canaanites may have deserved punishment, but so did the Israelite ... It seems inherently unfair to us to punish one party when both are guilty', Violence, Hospitality and the Cross: Reappropriating the Atonement Tradition (Grand Rapids: Baker, 2004): 84. Apart from what he would have said about something which seems 'inherently unfair to us', Calvin is here drawing attention to the peculiar degree or quality of Canaanite transgression. As the OT narrative rolls on, we know that Israel is capable of becoming as bad as and sometimes even worse than the other nations, but then God uses other nations to punish Israel.
} 
others will not want to lump all fighting adult males indiscriminately together in this particular context of moral judgement. But it is the unsparing extermination of the rest that causes wider difficulty. The appeal to divine justice in such a case, specifically a transcendent justice, which takes immanent form in history but requires little immanent justification, is subject to various objections. Four of them may be listed. Firstly, the word 'justice' is evacuated of meaning in this ('Calvin-type') defence, or it is being used equivocally. Secondly, the supposedly inscrutable justice involved here collides with God's public demonstration of the kind of justice that he loves, e.g. when instituting the laws by which the people of Israel are to live protectively towards the disadvantaged. Thirdly, there is no justice, manifest or transcendent, in slaughtering babies for the sin of Adam. Fourthly, even if God's justice means that we all deserve to perish or to be slaughtered, God's goodness and love disables an appeal either to manifest or to inscrutable justice in defence of such an alleged command.

Arguments and counter-arguments on this question are tractable up to a point and it is important to argue carefully for or against. Yet, it seems that fundamental intuitions will soon be seen to suffuse arguments pro and con and the mechanism by which to adjudicate these intuitions seems difficult to agree. What follows from this impasse? If it is, indeed, almost insuperably difficult to adjudicate between intuitions and to settle arguments, this will prove frustrating for some theologians, for it limits and even near-cripples the effective power and scope of theological reasoning, certainly in this domain. For others, the difficulty of resolution will prove illuminating rather than frustrating, bringing to light the form taken by the human apprehension of God, which is not subject to dispassionate theological appraisal. Of course, the role of intuition in theological (or philosophical or moral) argument is a subject in itself, although I am not binding my use of the word to a precise and technical philosophical sense. But, however we address the question of theological intuitions in general and whatever be said for or against Calvin's contention in particular, as I have laid it out briefly here, there is surely, at the very least, a dimension lacking in his treatment, and that of many who follow him. ${ }^{13}$ Identifying that lacuna

${ }^{13}$ I am simply thinking of the main line of Calvin's argument on the finality of the righteousness of God's will. I avoid comment on what Calvin says about infants deserving slaughter. 
will take us to the core of my proposal. In using the cold word 'proposal' in relation to such a painful subject, I want to offset its dispassion by expressing at least a measure of sympathy with the Holocaust survivor, Jean Améry, as he desperately sought to come to terms, in his writing, with the treatment of guilty perpetrators. Améry said: 'I had no clarity when I was writing this little book, I do not have it today, and I hope that I never will.' 14

I doubt if there is anything more arresting in Calvin's hermeneutics, or, indeed, his theology as a whole, than the way in which he understands divine accommodation. We probably associate this idea in Calvin mainly with speech-God in Scripture uses language accommodated to our weakness and capacity—but Calvin also talked about God's accommodated action and it is to this, albeit to its theological substance and not to Calvin's views on it, that we turn here. ${ }^{15}$ Post-diluvian history in Genesis is inaugurated not just under the sign of a rainbow in the heavens, but under the sign of a divine adjustment on the earth, conspicuously in terms of the permission to eat animals (apparently reversing the creation provision) and capital punishment (Gen. 9:1-7). This involves violence against both animals and humans. ${ }^{16}$ Violence dominates the post-lapsarian, pre-diluvian narrative scene. The flood is a violent judgement on human violence, a human violence said to cause God grief (Gen. 6:6). Grieved and grieving, God floods the world. So the book of Joshua is canonically contextualised, on the one hand, by God's hatred of the violent taking of life and, on the other, by God's promise of eschatological peace for humanity and creation, revealed in the prophets. Those who lambast the deeds of Joshua's God ought to allow initial quiet puzzlement to stifle immediate vocal protest as they bear this in mind.

God neither eliminates the evil which engulfs his world, whose presence is the dark mystery permeating the biblical story, nor allows it to run its untrammelled course. Where Scripture ever speaks of God appointing an activity that seems alien to his nature as expressed in his precepts, it is on the deep supposition that evil does not flow out of that

\footnotetext{
${ }^{14}$ Quoted in Thomas Brudholm, Resentment's Virtue: Jean Améry and the Refusal to Forgive (Philadelphia: Temple University Press, 2008): 72.

15 Jon Balserak, Divinity Compromised: A Study of Divine Accommodation in the Thought of John Calvin (Dordrecht: Springer, 2006) deserves careful study.

${ }^{16}$ The fate of animals causes Calvin little compunction: they 'were created for the sake of men and thus deservedly follow the fate of their owners' (7:24).
} 
nature and that his dealings with evil can take the form of channelling its force and course to his purposes. 'The Lord detests the way of the wicked' (Prov.15:9) and 'the Lord detests the thoughts of the wicked' (15:26); these sayings precede the insight that while, 'to man belong the plans of the heart ... from the Lord comes the reply of the tongue' (16:1) and while, 'in his heart a man plans his course ... the Lord determines his steps' (16:9). ${ }^{17}$ In relation to that causal chain which originates in the evil disposition of the heart and proceeds through motive, intention and plan to action, God is neither the active cause of the evil impulse nor the passive bystander who witnesses the autonomous process. God's opus proprium is blessing and the goodwe have learned that in the two opening chapters of the Bible and it is a lesson which should be drilled into us. However, God will not refrain from opus alienum and, indeed, we shall all be doomed if God not only allows evil to co-exist with him but also allows it to run its course completely uncontrolled, entirely permissively. It seems to me that John Goldingay is justified in speaking of God 'getting his hands dirty' in a kind of complicity with human action; God is both able and resolves to operate by an instrumentality which is not the original product of his own good and pure hands. ${ }^{18}$ The prophet Habakkuk was not alone in his perplexity as to how this could be so, but divine accommodation it certainly is, most costly to God, at that. I am not claiming that this account applies to all forms of evil, but it is germane in the present case.

Divine commands can thus be issued with a heavy heart-indeed, with the heaviest of hearts. Matthew reports a discussion between Jesus and Pharisees over divorce. When the Pharisees referred to a Mosaic command (eneteilato) in the matter, Jesus modified this to a Mosaic permission (epetrepsen) (Matt. 19:7-8). The Markan account presents an interesting contrast: Jesus asks the Pharisees what Moses commanded in the matter and they reply in the language of permission, using the same verbs as the Matthean in the respective cases (Mark 10:2-3). This reported exchange invites us to reflect on the conceptual point that command and permission are relative, not absolute, contrasts. Compared to the command in creation, Moses' prescription is

\footnotetext{
${ }^{17}$ These are my italics, of course.

18 'Justice and Salvation for Israel in Canaan' in Reading the Hebrew Bible for a New Millennium: Form, Concepts and Theological Perspective, ed. Wonil Kim et al (vol. 1; Harrisburg: Trinity, 200): 184.
} 
embedded in a concessionary, permissive context, overall. Mosaic command is contingent on a situation where things have badly broken down. In a fallen world, there are things which are, sadly, commanded; commanded sadly.

The Mosaic injunction in question does not provide us with an exact parallel to the Canaanite situation, not least because it terminates in prohibition or negative command and not, as is the case with the Canaanites, with a positive command. ${ }^{19}$ Nevertheless, I allude to it because Jesus' language highlights what the Deuteronomic text discloses, read against the background of Genesis, i.e. that a permissive: 'Given that this is the state of affairs on the ground' governs injunctions. Positive, rather than prohibitive, command is exemplified in such a case as Deuteronomy 21:18-21 and might also serve to make my point. Additionally, we seem to be faced with a set of circumstances very different from those pertaining to divorce in the case of the divine command to slaughter the Canaanites, not only when viewed under the aspect of literary form, but also where conceptual content is concerned. I certainly do not want to force isomorphism. But the command in Joshua is bounded by a vast and overarching permissive framework, when compared with anything contemplated in the pure creation order. The very possibility of taking life is the product of the fall; the command to take life assumes innate sklerrocardia, 'hardness of heart', to use the word that Jesus uses to describe the circumstance which led Moses to institute under God his regulations for divorce. So familiar are we with violence that we are apt to overlook its evil. Even the judicial decree of life for life, enjoined and applied in its purest form, is a divine use of human predilection to violence possible only in a world bound up with the sin of Adam. We are meant to read Joshua in its canonical context, where we have already learned of divine grief on account of human violence; already learned of divine accommodation to human ways; where we shall learn that God cares for lilies and sparrows; where we shall learn that he will establish, to his own delight, shalom. The upshot is surely this: we must say that, if God commanded the slaughter of the Canaanites, it was with an immeasurably heavy heart.

${ }^{19}$ I am grateful to the anonymous reader of this article for tidying up my reasoning in this paragraph. 
Perhaps, for many, this is just to state the obvious. But it picks out a dimension frequently missing in the averments of those who assign justice and goodness to God in all his commands and virtually leave it there. I am not denying that we can appropriately speak of divine justice and goodness in connection with this command, relative to the earthly and fallen state of affairs. With respect to infants, for example, however we react to the connection that he affirms between original sin and infant desert (and this is as far as can be from a trifling affirmation to be treated in dispassionate parentheses), let us say this and word it very precisely: Calvin was not wrong to introduce for our consideration the question of infant immortality as he pondered the justice of their slaughter, if that is how we should interpret his words, and whether or not we actually conclude that it should be factored into any substantive theological resolution. ${ }^{20}$ Moving from divine justice to divine goodness, it is likewise proper to recall what the effect on Israelite life would have been if a generation of Canaanite children had survived, raised by their mothers to seek vengeance for the slaughter of their fathers. And a people of God which succumbed so readily to the gods of Canaan would not have converted surviving women and children into lovers of Yahweh; the course of Israel's history showed how desperately bad things became socially even when the people lived under God's formal prohibition of idolatry. I am not denying that all this rightly forms part and parcel of our theological reflection. Considerations of justice and goodness apart, the narrative itself highlights God's holiness most of all, amongst his perfections; the very extremity of the action enjoined upon the Israelites in Canaan is viewed as displaying that holiness and a sinful world needs some form of display, under conditions of monstrous universal violence.

However, if considerations along all these lines are advanced in order to square divine justice, goodness and holiness with the slaughter of the Canaanites in tandem with an appeal to the inscrutability of God's justice or other attributes, such a theology justifiably provokes

\footnotetext{
${ }^{20}$ Without trying to decide whether this is a matter of theological weight in the present context, it is perhaps worth noting that, in the very introduction to his comprehensive systematic exposition of Christian theology, even before he embarks on the detailed adumbration of his system, Charles Hodge insists that all infants will be saved and that this is the Reformed position, Systematic Theology (Grand Rapids: Eerdmans, 1993): 26-27. B. B. Warfield was more cautious and more accurate in relation to the Reformed tradition, but sympathetic to Hodge here: Studies in Theology (London: Oxford University Press, 1932): chapter 14.
} 
dismay unless it incorporates at its heart God's sorrowful accommodation. When we consider Joshua, we must foreground theologically the canonical context and insist that, if God could have commanded the slaughter of the Canaanites, it could only have been with the heaviest of hearts, channelling a human impulse to kill, an impulse which is the most dreadful sign and manifestation of disorder and fall. It is not thus that God would gladly express or reveal the glories of his nature. This theological interpretation is not advertised in the book of Joshua, but the book of Joshua makes fatal reading unless it is read as part of the canon of Christian Scripture, with emphasis on the first nine chapters of its first book.

Is the position which I am advancing here heavily dependent on the denial of divine impassibility and on the literal ascription of grief to God? If so, some of us, including myself, will have no problem with that. Those who reject passibility, but who wish to salvage something positive from the foregoing argument, will propose some modification to it. It goes without saying that impassibility requires independent attention in its own theological right and that the meaning of 'literal' ascriptions has to be explicated. It appears to be a serious understatement to describe my position in terms of identifying a dimension missing in Calvin; surely, the introduction and application of passibility entails that the line taken here is completely at odds with him. Perhaps that is so. But I confess to a twinge of doubt. It is not altogether clear to me that the alternative perspective to his, offered here, is thoroughly alien to something very deep in Calvin's religious sensibility, emergent in a strand of his theology. How so?

Calvin's work consistently exudes both a sense of the misery and tragedy of human life and suffering and also a sense of the transcendent inscrutability of the ways of God. We find it in the commentary on Joshua; we find it somewhat in the Institutes; we find it everywhere in that most revealing of Calvin's works, his lengthy Sermons on Job. ${ }^{21}$ The latter, in particular, show how human suffering is a major factor

21 Calvin, Sermons on Job (Edinburgh: Banner of Truth, 1993 repr.). Susan E. Schreiner's: Where Shall Wisdom Be Found? Calvin's exegesis of Job from medieval and modern perspectives (Chicago: University of Chicago Press, 1994) is a helpful work. The Institutes is a turbulent work and shuddering turbulence surrounds Calvin's announcement of God's 'dreadful decree' that humans, including infants, should perish in Adam by God's good pleasure, although, at this point, it seems to be the turbulence of dread or awe more than of sorrow. For this, see Calvin, Institutes of the Christian Religion ( vol.2; Philadelphia: Westminster, 1960; tr. by F. L. Battles): 3.23.7. 
generating his sense and conviction of divine inscrutability. It forces us to ask: if God is as mysterious as he is for Calvin, can we know enough about him to deny categorically a form of transcendent divine sorrow? Calvin's insistence that we should not predicate of God either wrath or repentance, for these are forms of accommodated speech ascribing to him emotion, certainly rules out passible change. ${ }^{22}$ But what is the exact scope of Calvin's principle of accommodation? Of God's command in general, Karl Barth said: 'Either we hear it as the command of His goodness (even though it is a command to shoot) or we do not hear it at all', a remark that clearly bears on our theological appropriation of Joshua. ${ }^{23}$ On the face of it, Calvin would have heartily agreed. My argument entails a qualification of Barth's claim as it stands. ${ }^{24}$ Yet the combination of transcendent inscrutability and the remarkable range of God's accommodations in Calvin's thought makes me hesitant to be quite confident of where exactly my position stands in relation to that of Calvin. ${ }^{25}$ However, the gulf between any putative 'transcendent sorrow' in Calvin and my description of divine heavyheartedness may, at the very least, deprive them of any significant positive connection. '....Let us mark well that by our sinning we hurt not God. ${ }^{26}$ In relation to divine grief, Calvin would appear to take as accommodated language what I am taking more literally, to put it roughly.

Be all this as it may, in modulating divine command along the lines of the argument above, two things are assumed about divine command itself. The first is that it is a coherent and meaningful notion. It may seem philosophically easier to say that we should speak of our experiencing ' $x$ ' as divine command rather than of ' $x$ ' being divine command. But how far would this amendment take us? It obviously leaves open the question of whether God did, in fact, command it, and, if we agree that it is appropriate to speak of ' $\mathrm{x}$ ' as being experienced as a divine command on condition that God intends it to be so

\footnotetext{
${ }^{22}$ Calvin, Institutes (vol.1; Philadelphia: Westminster, 1960): 1.17.13.

${ }^{23}$ Church Dogmatics II/2 (Edinburgh: T\&T Clark, 1957): 712.

${ }^{24}$ It may be unfair to wonder whether Barth is bordering on being glib with this formulation, but I am not concerned here to pursue this in connection with Barth's views on divine impassibility.

25 I simply have this question in mind, not the detailed particulars of Calvin's discussion of Joshua. For a particularly intriguing appeal to accommodation in the Institutes, see vol.1, 2.16.2-4.

${ }^{26}$ Calvin, Sermons on Job, 642.
} 
experienced, those who worry about the concept of divine command will presumably worry equally about the concept of divine intention. The second is that it is right to do ' $x$ ' if God commands ' $x$ '. In affirming this, we may or may not be affirming a theory of moral obligation. What we are certainly doing is identifying a feature of moral obligation. Such is the relation between God and humanity in the biblical account that we ought to obey his commandments. This underlies the moral theology of the book of Joshua, as that of Scripture as a whole. Like the first assumption, it is taken for granted, and not defended, in my discussion, because its exploration would take us too far afield.

In conclusion, it must be underlined that the account in Joshua does not propose a permanent norm of conduct. It does not do so on its own terms; its distinction, even within the OT, from other military operations (as indicated earlier) illustrates this. Still, it may be thought that the distinction should not be exaggerated and that the peculiarities of Canaanite slaughter nestle uncomfortably close to the wider stream of Israelite violence, particularly when we read the account of Samuel, Saul and the Amalekites (1 Sam. 15:1-35). What is decisive is God's dispensational economy, whose moral apex, as far as Christians are concerned, is the form of life to which we are summoned in Jesus Christ. Joshua's aeon has gone for ever. But, despite the novelty of the covenant which inaugurates our new aeon, can we be categorically certain that we inhabit times in which the command given to Joshua can never apply again? Allow that God could once have commanded the slaughter of the Canaanites and can you be confident that this can never, albeit very exceptionally, be commanded in the Common Era? For will not sons of Adam and daughters of Eve soon be open to the possibility that they are privy to that exceptional circumstance?

To this, we must surely reply that the account of slaughter in Joshua gives us no positive purchase whatsoever on the possibility that a corresponding act, transposed into a different historical context, could be commanded in our time. It is one thing to line up a range of activities that we might judge evil, immoral or cruel and ask of each: could God ever command in our day ' $x$ ', ' $y$ ' and ' $z$ ', and include the slaughter of children as an example. If we raised the question in that form, it would be a question about the boundaries of divine command either in all times and places or in our particular time and place. Whatever the answer we gave, Canaanite-type slaughter would, in that 
case, be a particular instance of a variety of evils that we should be specifying, asking of each whether God could have commanded and could ever now command such a thing. However, the point to press here is this: from the fact that this particular command could have been issued once upon a time, no specific possibility accrues for the present possibility of Canaanite-type slaughter. As a general question, people may want to debate whether God can or can not command genocide in our aeon, although will the prospect of debate not chill the blood? But the possibility that God could command genocide today is neither established nor enhanced by the belief that, once upon a time, he might, indeed, have commanded what he was said in the book of Joshua to command. I have sought to reflect on the theological conditions that must obtain if someone answers in the affirmative the question: could God have commanded the slaughter of the Canaanites? But, as the older translation has it, we now see in a glass darkly (1 Cor. 13:12). It is we who have brought about the darkness-darkness of a different sort. He whom we hope to see one day is light, in whom there is no darkness at all (1 John 1:5). 